\title{
A survey of the pH status and related fertility factors of sugarcane fields of Puerto Rico ${ }^{1,2,3}$
}

\author{
Antonio Vélez-Ramos' and Miguel A. Muñozs
}

\begin{abstract}
A field survey was initiated in the main sugarcane production areas of Puerto Rico to determine the pH status of sugarcane soils and those specific soil factors that influence growth and development, such as exchangeable cations, percentage base saturation (\% BS) and lime requirement. Soil samples from Coloso, Plata, Arecibo, Humacao, Yabucoa and Eureka areas were analyzed for $\mathrm{pH}$, available $\mathrm{P}$, Fe and $\mathrm{Mn}$; exchangeable $\mathrm{K}, \mathrm{Ca}, \mathrm{Mg}$

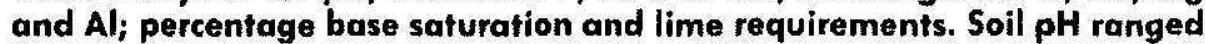
from as low as 3.2 to a high of 8.1. Sixty-eight percent of the soil samples analyzed showed pH values below 5.5. The lowest soil pH valules were observed in the Eureka area and the highest in Arecibo, whereas in the Coloso, Plata, Humacao and Yabucoa areas pH values were intermediate with readings befween 4 and 5 as an average. Eighty percent of the soil samples from Plata, $40.0 \%$ of those from Eureka and $40.5 \%$ of those from Coloso had pH values below 4.5. All soil samples collected in Humacao and Yabucoa (except one) showed pH values below 5.5. No definite trend was observed when sugarcane yield per acre and soil pH for the YabucoaHumacao area were compared. In general, $\mathrm{P}$ and $\mathrm{K}$ were low in all regions sampled, whereas $\mathrm{Ca}$ and $\mathrm{Mg}$ values were higher in the Coloso than in the Yabucoa-Humacao regions. Soils from the Coloso region showed higher levels of exchangeable $\mathrm{Al}$ and higher percentages of Al saturation than soils from the Yabucoa-Humacao region. This fact, together with a lower $\%$ BS should aggravate acidity problems in the Coloso region. Percentage base saturation was good at the higher $\mathrm{pH}$ readings.
\end{abstract}

\section{RESUMEN}

Estudio sobre el pH y los componentes de fertilidad de los suelos dedicados al cultivo de la caña de azúcar en Puerto Rico

Se realizó un estudio de campo en zonas productoras de caña de azúcar seleccionadas de antemano en las regiones este, oeste y norte de Puerto Rico para determinar el pH del suelo y otros factores asociados con la fertilidad, tales como $\mathrm{P}$, Fe y $\mathrm{Mn}$ disponible, $\mathrm{K}, \mathrm{Ca}, \mathrm{Mg}$ y $\mathrm{Al}$ infercambiable y porcentaje de saturación de bases. Se tomaron 218 muestras de suelo en las zonas de Eureka, Coloso, Arecibo, Humacao, Yabucoa y Fajardo, un área de aproximadamente 37,000 cuerdas ${ }^{\circ}$ de terreno dedicado al cultivo

'Manuscript submitted to Editorial Board 5 July 1990.

${ }^{2}$ The data from which this study was developed was collected in cooperation with field personnel of the Sugar Corporation of Puerto Rico.

Investigator, Department of Agronomy and Soils.

Assistant Investigator, Department of Agronomy and Soils.

'The authors thank Mr. Oscar Muñiz, Soil Specialist, Agricultural Extension Service, for his valuable assistance during the study and for reviewing the manuscript.

6.97 acre; 0.39 hectare. 
practices. The major soil series and their classification for each sugarcane area are included in table $1(6)$.

A composite soil sample of 0 to 8 inches of top soil was taken from each sampling unit, which consisted of about 25 to 200 acres. A total of 218 soil samples were collected from an area of 36,900 acres (fig. 1). Samples were analyzed by the Central Analytical Laboratory of the Agricultural Experiment Station and the Agrological Laboratory of the Department of Agriculture at Dorado, P.R. for $\mathrm{pH}, \mathrm{P}, \mathrm{K}, \mathrm{Ca}, \mathrm{Mg}, \mathrm{Fe}$, $\mathrm{Al}, \mathrm{Zn}$, total exchangeable bases, percentage base saturation and lime requirement for specific samples. Phosphorus was extracted by the Bray I method for acid soils and by the Olsen method for alkaline soils. The extraction of $\mathrm{Fe}$ and $\mathrm{Mn}$ was made with an acid mixture of $0.05 \mathrm{~N} \mathrm{HCl}$ $+0.025 \mathrm{~N} \mathrm{H}_{2} \mathrm{SO}_{4}$, whereas exchangeable $\mathrm{Ca}, \mathrm{Mg}$ and $\mathrm{K}$ were extracted with ammonium acetate at $\mathrm{pH} 7$ (7). All cations were determined by atomic absorption spectroscopy. Soil $\mathrm{pH}$ was determined in a 1:2 soil:water ratio $(20 \mathrm{~g}$ in $40 \mathrm{ml})$.

\section{RESULTS}

Soils were grouped according to $\mathrm{pH}$ readings, in six categories as follows: $\mathrm{pH}<4.00,4.01$ to $4.50,4.51$ to $5.00,5.01$ to $5.50,5.51$ to 6.00 and $>6.00$. Two hundred eighteen composite soil samples were collected in the five regions under study.

Table 1 presents the number of samples and the percentage of samples for each area under each $\mathrm{pH}$ range. Table 2 shows acreage of land under each $\mathrm{pH}$ group by region. The most acid soil samples were obtained from Yabucoa, Humacao and Eureka. Arecibo showed the highest $\mathrm{pH}$

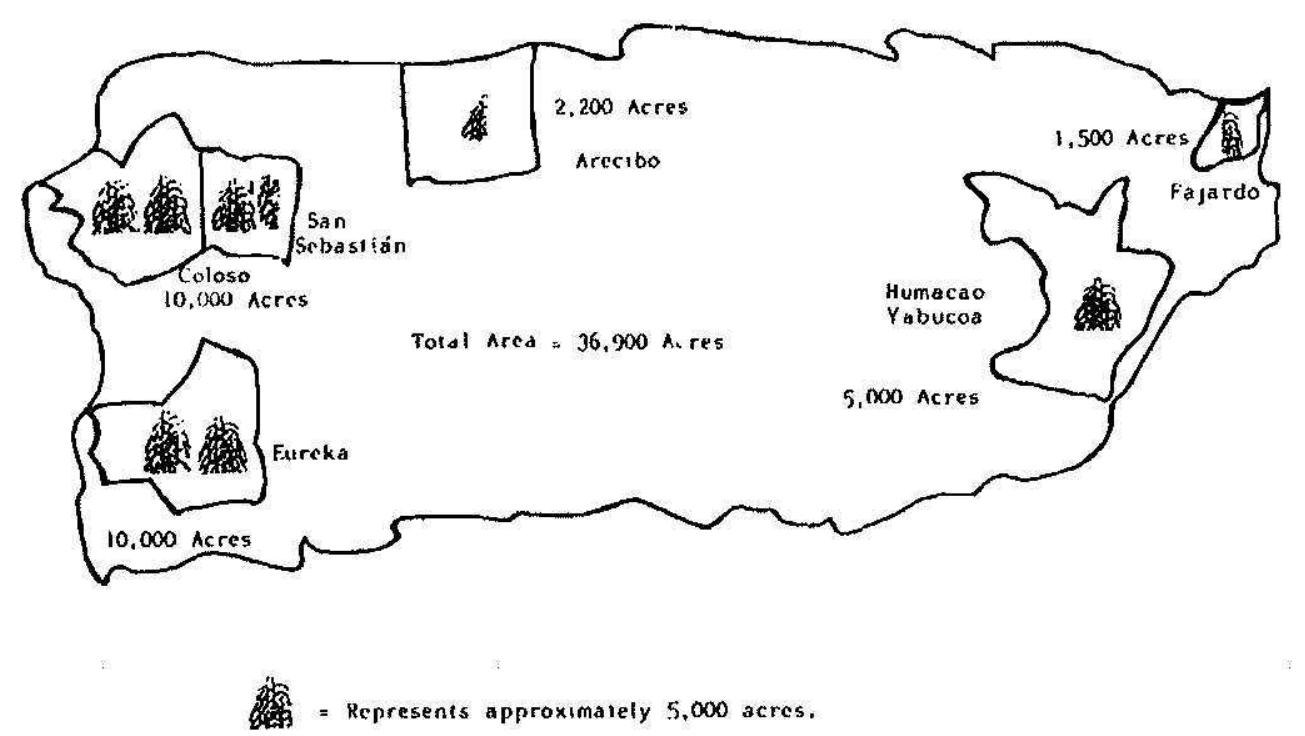

Fig. 1-Sugarcane production areas included in the study. 
TABLE 1.-Number and percentage of soil samples under each pH range by sugar cane region

\begin{tabular}{crrrrrrrrrrr}
\hline & $\begin{array}{c}\text { Yabucoa } \\
\text { Humacao }\end{array}$ & \multicolumn{2}{c}{ Coloso } & Plata & Eureka & Arecibo & Total \\
\hline $\begin{array}{c}\text { pH } \\
\text { Range }\end{array}$ & $\begin{array}{c}\text { No of } \\
\text { samples }\end{array}$ & $\begin{array}{c}\text { No. of } \\
\text { samples }\end{array}$ & $\begin{array}{c}\text { \%o. of } \\
\text { samples }\end{array}$ & $\begin{array}{c}\text { No. of } \\
\text { samples }\end{array}$ & $\begin{array}{c}\text { No. of } \\
\text { samples }\end{array}$ & $\begin{array}{c}\text { No. of } \\
\text { samples }\end{array}$ \\
\hline$<4.00$ & 2 & 3.6 & 1 & 1.6 & 3 & 6.0 & 8 & 20.0 & 0 & 0.0 & 14 \\
$4.01-4.50$ & 10 & 17.8 & 11 & 17.8 & 22 & 44.0 & 3 & 20.0 & 0 & 0.0 & 46 \\
$4.51-5.00$ & 31 & 55.4 & 8 & 12.9 & 18 & 36.0 & 2 & 25.0 & 0 & 0.0 & 59 \\
$5.01-5.50$ & 11 & 19.6 & 5 & 8.1 & 1 & 2.0 & 2 & 10.0 & 4 & 13.3 & 23 \\
$5.51-6.00$ & 2 & 3.6 & 2 & 3.2 & 1 & 2.0 & 3 & 15.0 & 1 & 3.3 & 9 \\
$>6.00$ & 0 & 0.0 & 35 & 56.4 & 5 & 10.0 & 2 & 10.0 & 25 & 83.4 & 67 \\
& 56 & 100.0 & 62 & 100.0 & 50 & 100.0 & 20 & 100.0 & 30 & 100.0 & 218 \\
\hline
\end{tabular}

readings. Assuming that the ideal soil $\mathrm{pH}$ for optimum sugarcane growth and yield is $5.5,68.7 \%$, or 25,337 acres, of the total area under study falls below that mark. Nearly 21,728 acres or $58.9 \%$ has a pH below 5.00 and needs liming. This prediction is based on the assumption that each soil sample is a true representative of the particular farm where it was taken. Although this assumption was not statistically evaluated, it is useful to give an educated guess of the reality. The results herein reported are similar to those of Samuels (8), who found that $55.3 \%$ of the soils planted to sugarcane in Puerto Rico had pH values below 5.5.

Figure 2 shows the position of each soil sample by region on a $\mathrm{pH}$ scale ranging from 3 to 8 . The majority of the samples fall in a pH range between 4.2 and 5.4. Such soils need liming. Data in table 3 present the acres of sugarcane land with $\mathrm{pH}$ values below 5 , which are in immediate need of liming. An estimate of the total tons of lime that would be required to raise the $\mathrm{pH}$ to 5.5 is also included. The estimate is based on the assumption that as an average, 2 tons of lime would increase soil $\mathrm{pH}$ from values below 5.00 to 5.50 . According to the data, $60 \%$ of the land

TABLE 2.-Acreage of sugar cane in each $p H$ range by region

\begin{tabular}{crrrrrr}
\hline pH & $\begin{array}{r}\text { Humacao } \\
\text { Yabucoa }\end{array}$ & Coloso & Plata & Eureka & Arecibo & Total \\
\hline$<4.00$ & 252 & 160 & 462 & 2,000 & 0 & 2,874 \\
$4.01-4.50$ & 1246 & 1780 & 3388 & 2,000 & 0 & 8,414 \\
$4.51-5.00$ & 3878 & 1290 & 2772 & 2,500 & 0 & 10,440 \\
$5.01-5.50$ & 1372 & 810 & 154 & 1,000 & 293 & 3,629 \\
$5.51-6.00$ & 252 & 320 & 154 & 1,500 & 72 & 2,298 \\
$>6.00$ & 0 & 5640 & 770 & 1,000 & 1835 & 9,245 \\
\hline Total & 7,000 & 10,000 & 7,700 & 10,000 & 2,200 & 36,900 \\
\hline
\end{tabular}




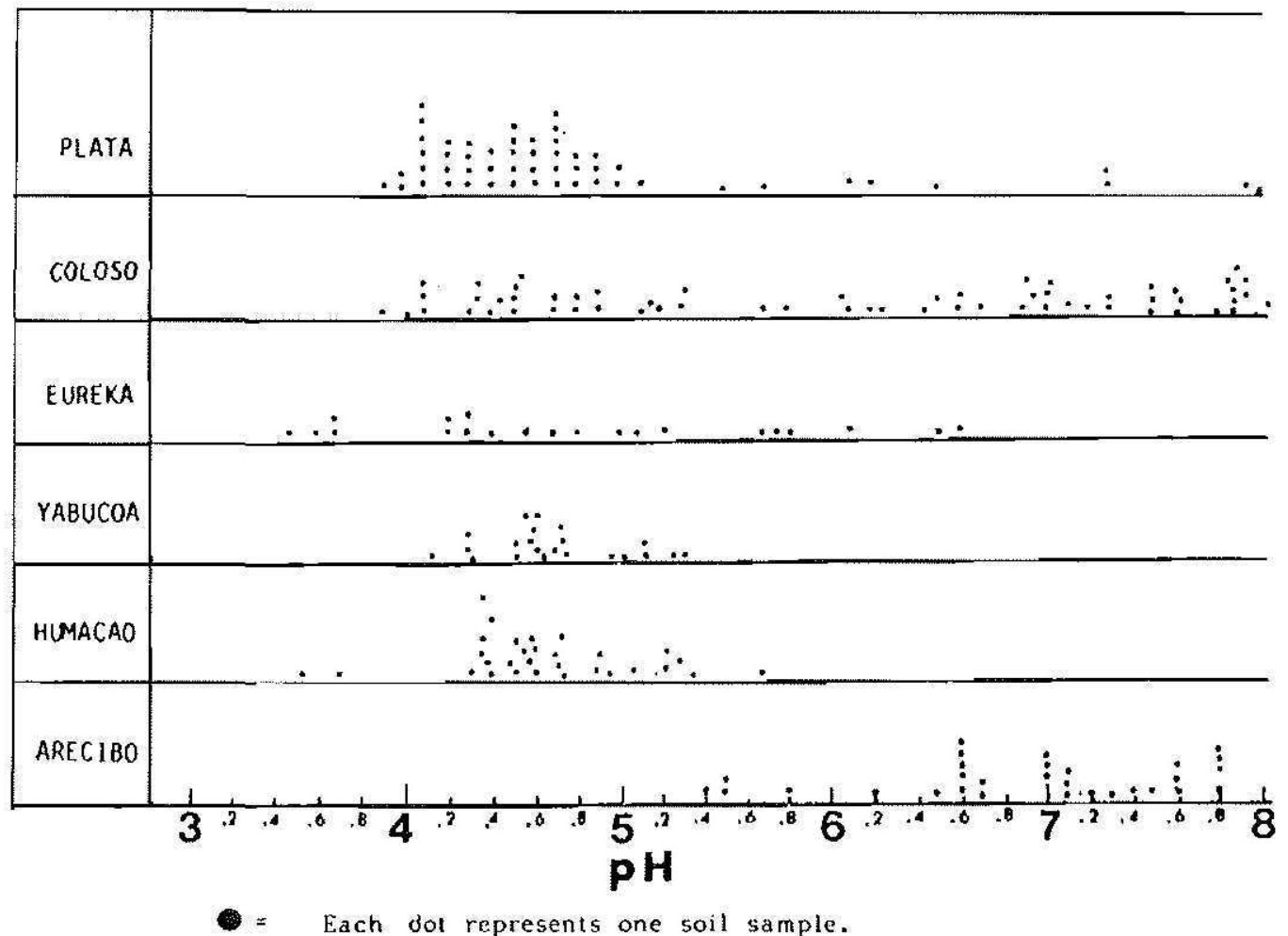

Fig. 2 Soil pH from samples taken in various sugarcanee areas in Puerto Rico.

evaluated (21,728 acres) falls in the low $\mathrm{pH}$ category, requiring 43,456 tons of lime.

Soil samples from Yabucoa, Humacao and Coloso were evaluated for other fertility factors (table 4). Soil phosphorus content for the YabucoaHumaca o area seems to be adequate at all $\mathrm{pH}$ levels; however, soil potas-

TABLE 3.-Estimated amount of lime required to increase soil $p H$ to 5.5

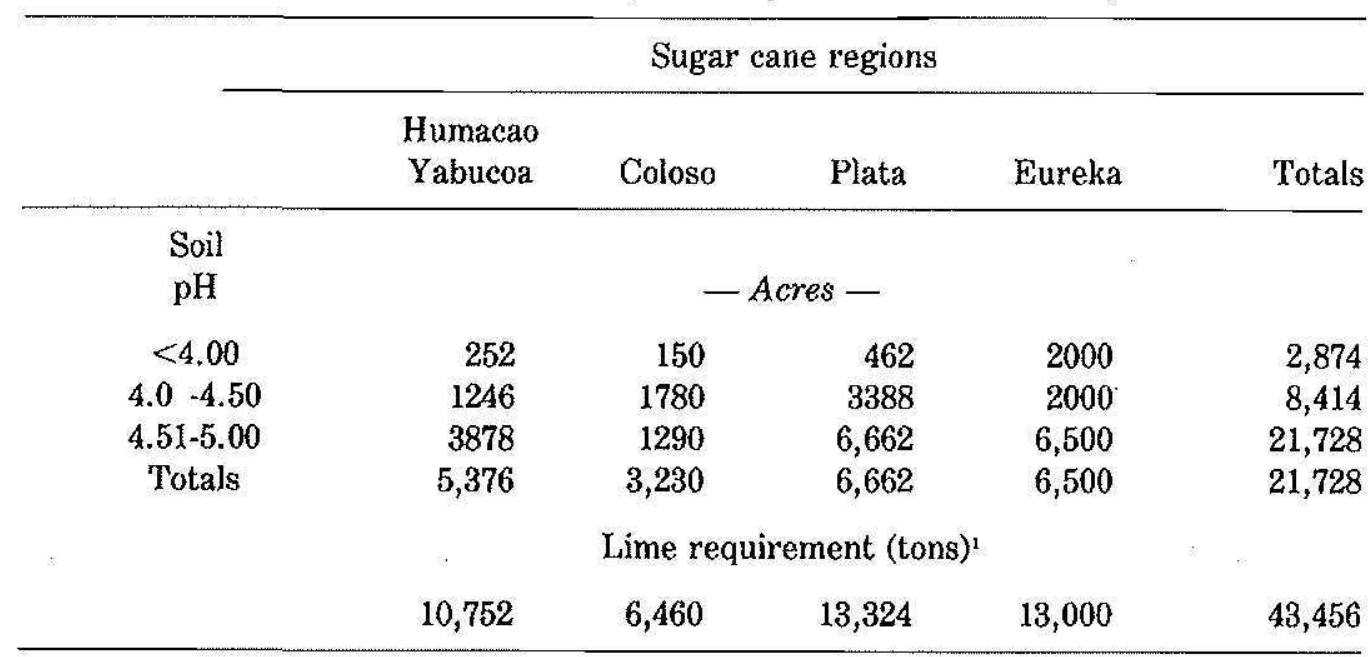

'Assuming that, on an average, 2 tons of lime will increase soil $\mathrm{pH}$ from below 5.0 to 5.5 
TABLE 4,-Components of soil fertility at various soil pH levels

\begin{tabular}{|c|c|c|c|c|c|c|c|c|c|c|}
\hline $\mathrm{pH}$ & $\mathrm{P}$ & $\mathrm{Fe}$ & Mn & $\mathrm{Ca}$ & K & $\mathrm{Mg}$ & $\mathrm{AL}$ & $\mathrm{CEC}$ & $B s^{3}$ & Sat. AL \\
\hline Yabucoa-Humacao & \multicolumn{3}{|c|}{$-p / m-\ldots$} & \multicolumn{7}{|c|}{ meq/100g $\%$} \\
\hline 4.00 & 30 & $*_{1}$ & 32 & 1.70 & 0.20 & 0.68 & 3.0 & 7.03 & * & 43 \\
\hline $4.01-4.50$ & 53 & 9 & 63 & 2.24 & 0.23 & 0.84 & 2.0 & 33.0 & 28 & \\
\hline $4.51-5.00$ & 51 & 11 & 110 & 3.84 & 0.21 & 1.53 & 1.7 & 7.72 & 51.6 & 22 \\
\hline $5.01-5.50$ & 30 & 6 & 76 & 5.65 & 0.15 & 2.50 & N.D. & 8.60 & 68.7 & 0 \\
\hline $5.51-6.00$ & 42 & $*$ & $*$ & 7.48 & 0.15 & 5.88 & * & 13.51 & 84.4 & 0 \\
\hline 6.00 & 2 & & & & & & & & & \\
\hline \multicolumn{11}{|l|}{ Coloso } \\
\hline$<4.00$ & 6 & 30 & 21 & 0.38 & 0.08 & 0.33 & 9.6 & 10.47 & 4.9 & 92 \\
\hline $4.01-4.50$ & 29 & 8 & 121 & 3.11 & 0.29 & 1.88 & 3.6 & 9.36 & 22.0 & 38 \\
\hline $4.51-5.00$ & 11 & 14 & 174 & 7.07 & 0.28 & 3.79 & 0.88 & 12.72 & $*$ & 7 \\
\hline $5.01-5.50$ & 20 & * & $*$ & 13.37 & 0.37 & 6.96 & N.D. & 20.70 & * & 0 \\
\hline $5.51-6.00$ & 20 & * & * & 18.88 & 0.22 & 7.17 & N.D. & 26.27 & * & 0 \\
\hline$>6.00$ & 27 & N.D. & * & 6.75 & 0.32 & 7.21 & N.D. & 24.28 & * & 0 \\
\hline
\end{tabular}

'No information available.

${ }^{2}$ Soil samples not analyzed.

${ }^{3}$ Base saturation.

sium is low. A value of $0.38 \mathrm{meq} / 100 \mathrm{~g}(150 \mathrm{p} / \mathrm{m})$ is frequently considered high enough to ensure adequate $\mathrm{K}$ supply for plant growth (1). $\mathrm{Ca}$ and $\mathrm{Mg}$ for this area, as expected, were higher in soils with higher $\mathrm{pH}$ levels, but the ratio of $\mathrm{Ca:Mg}$ was around 2.5:1, which is far below the ideal $6: 1$ ratio (2). The percentage base saturation (\% BS) was higher with increased soil $\mathrm{pH}$, with the highest percentage at $\mathrm{pH}$ values around 6 .

Soil available phosphorus for the Coloso area is much lower than that for the Yabucoa-Humacao area and definitely lower than the adequate level $(35$ to $40 \mathrm{p} / \mathrm{m})$. The high $\mathrm{Fe}$ and $\mathrm{Al}$ content on soils from the Coloso area may be the major factor influencing $\mathrm{P}$ availability. At low soil $\mathrm{pH}$ values, $\mathrm{Fe}$ and $\mathrm{Al}$ phosphates of extremely low solubility are readily formed. Potassium content is higher than that for the areas of reference, but lower than the ideal levels of 140 to $150 \mathrm{p} / \mathrm{m}$. Soils from the Coloso area also had higher cation exchange capacity values than the soils from Yabucoa-Humacao. Both soil $\mathrm{Ca}$ and $\mathrm{Mg}$ content for the Coloso area were higher than for the Yabucoa-Humacao area but the Ca:Mg ratio was lower. While the Ca: $\mathrm{Mg}$ ratio of Coloso soils increased as soil $\mathrm{pH}$ increased, the opposite was observed for the Yabucoa-Humacao soils (fig. 3). The contrasting trends of Ca:Mg ratios for both groups of soils may be related to differences in mineralogy and organic matter content. Although the \% BS data are incomplete, there is a similar trend for the eastern area.

Soil content of $\mathrm{Mn}, \mathrm{Fe}$ and $\mathrm{Al}$ at corresponding $\mathrm{pH}$ range is within the expected levels. The availability of these three elements is highly 


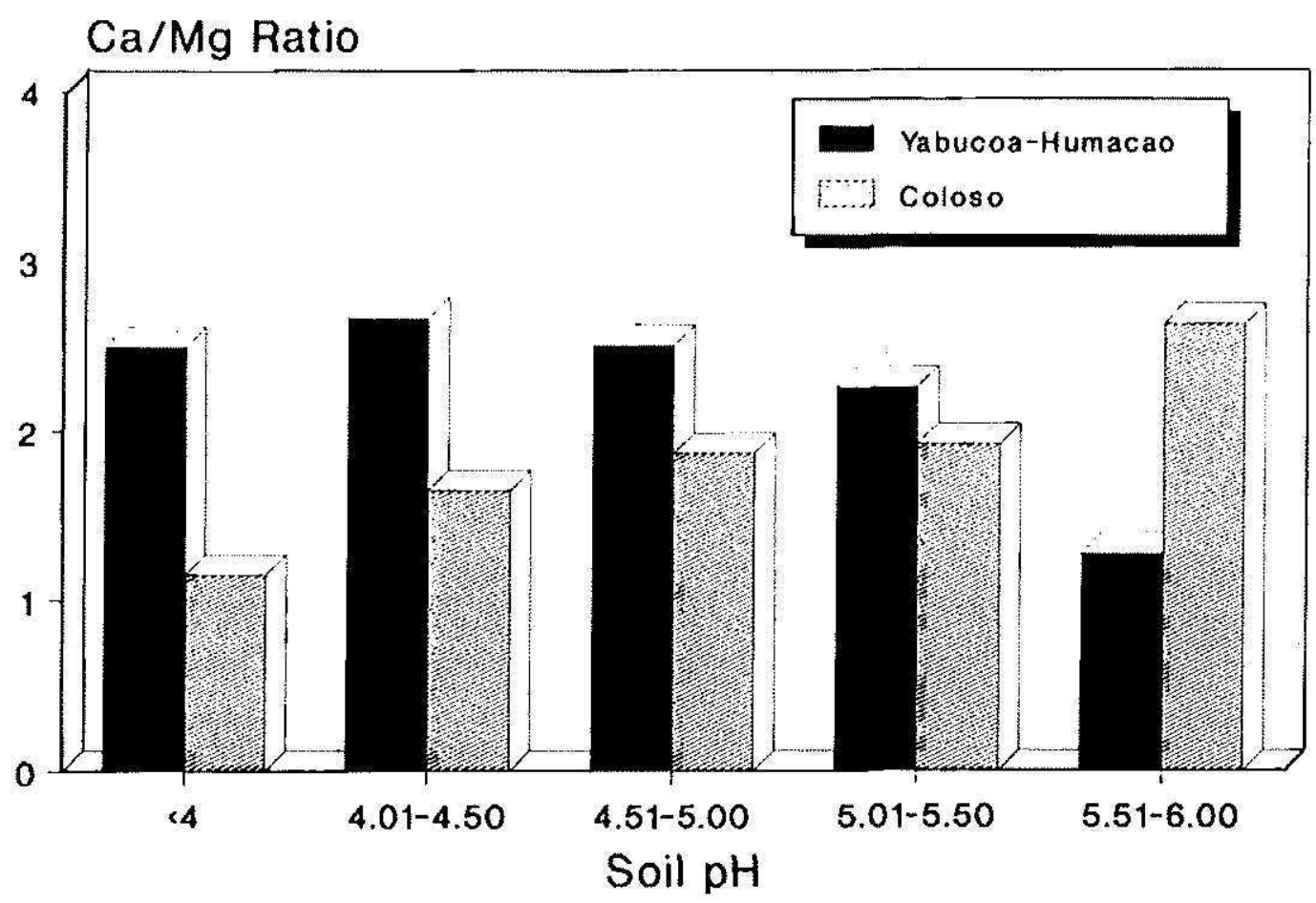

Fig. 3-Calcium/magnesium ratios of Coloso and Yabucoa-Humacao soils.

controlled by soil $\mathrm{pH}$. The higher levels of exchangeable $\mathrm{Mn}$ were observed in the $\mathrm{pH}$ range of 4.51 to 5.00 , whereas higher levels of exchangeable Al were observed at $\mathrm{pH}$ values below 4.50 (table 4). Soils from the Coloso area experienced higher exchangeable $\mathrm{Al}$ content than soils from Yabucoa-Humacao. A plot of exchangeable Al vs. $\mathrm{pH}$ for soil samples from both areas is presented in figure 4. A highly significant correlation was observed $\left(\mathrm{R}=0.87^{* *}\right)$, with exchangeable $\mathrm{Al}$ decreasing as the $\mathrm{pH}$ increased. The data conform best to a third degree polynomial equation; however, a highly significant correlation $\left(\mathrm{R}=0.80^{* *}\right)$ was also obtained when the data were fitted to a second degree polynomial equation. Exchangeable Al ranged from 9.60 to $0.30 \mathrm{meq} / 100 \mathrm{~g}$ as the $\mathrm{pH}$ ranged from 4.00 to 5.00 . For many crops, levels of exchangeable $\mathrm{Al}$ above $0.60 \mathrm{meq} /$ $100 \mathrm{~g}$ will reduce root and shoot growth (1). About $80 \%$ of the samples with $\mathrm{pH}$ values below 5.00 showed $\mathrm{Al}$ content above that level.

An attempt was made to obtain cane and sugar yield data for specific farms. The information was available only for the Yabucoa-Humacao area. Figure 5 shows yield in tons of cane per acre vs. $\mathrm{pH}$. Although high soil acidity is well known to retard plant growth and reduce yields, no definite relation between soil $\mathrm{pH}$ and yield was observed. High sugarcane yields were observed at low and high $\mathrm{pH}$ values. Other factors, such as soil fertility level, soil texture, available water, organic matter content and crop management could be masking the effect of soil $\mathrm{pH}$ on yield. 
J. Agric. Univ. P.R. voL. 75, No. 3, JuLx, 1991

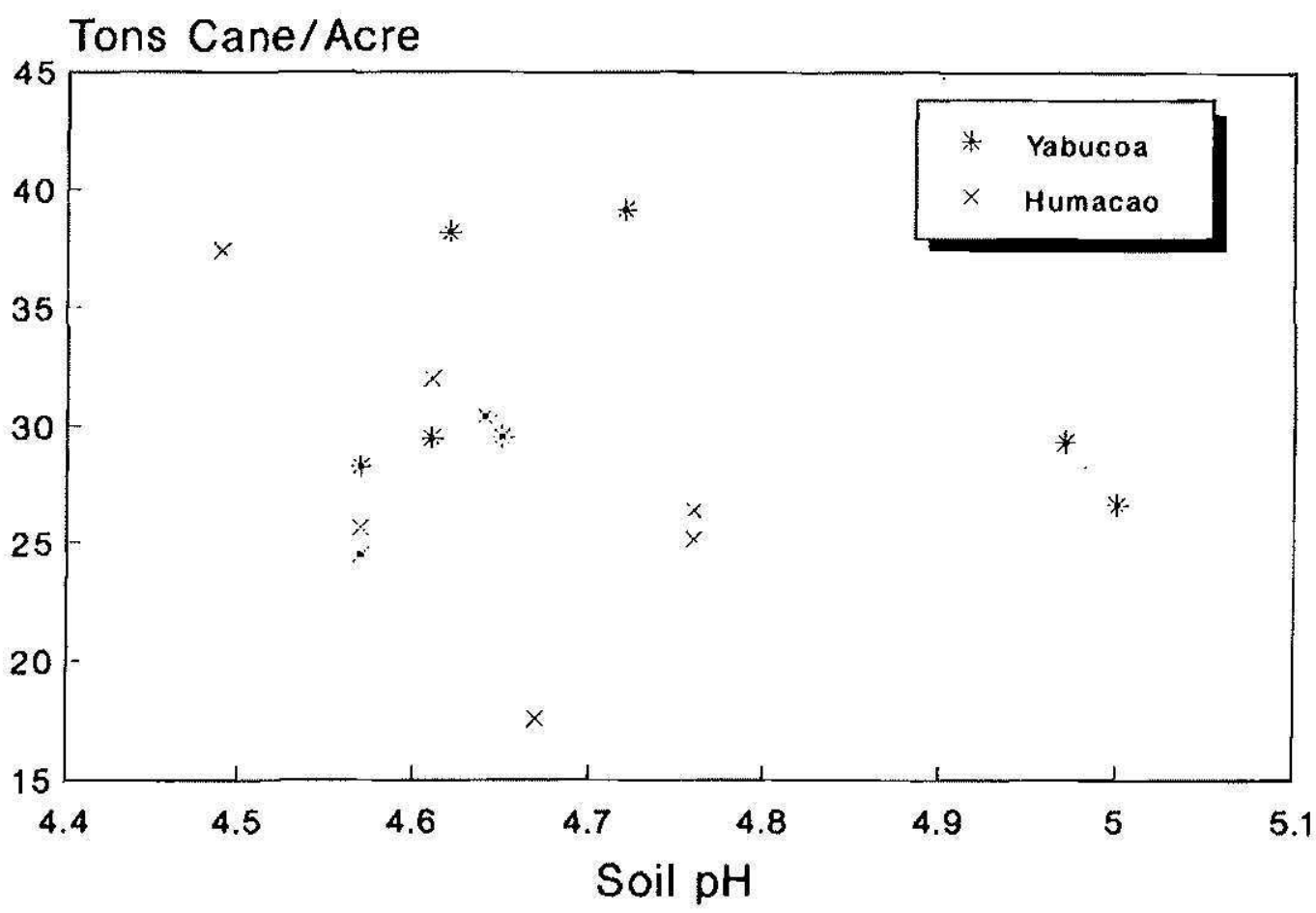

Fig.4-Relationship between $\mathrm{pH}$ and exchangeable $\mathrm{Al}$ for Coloso and Yabucoa-Humacao soils.

\section{Exchangeable Al (meq/100g)}

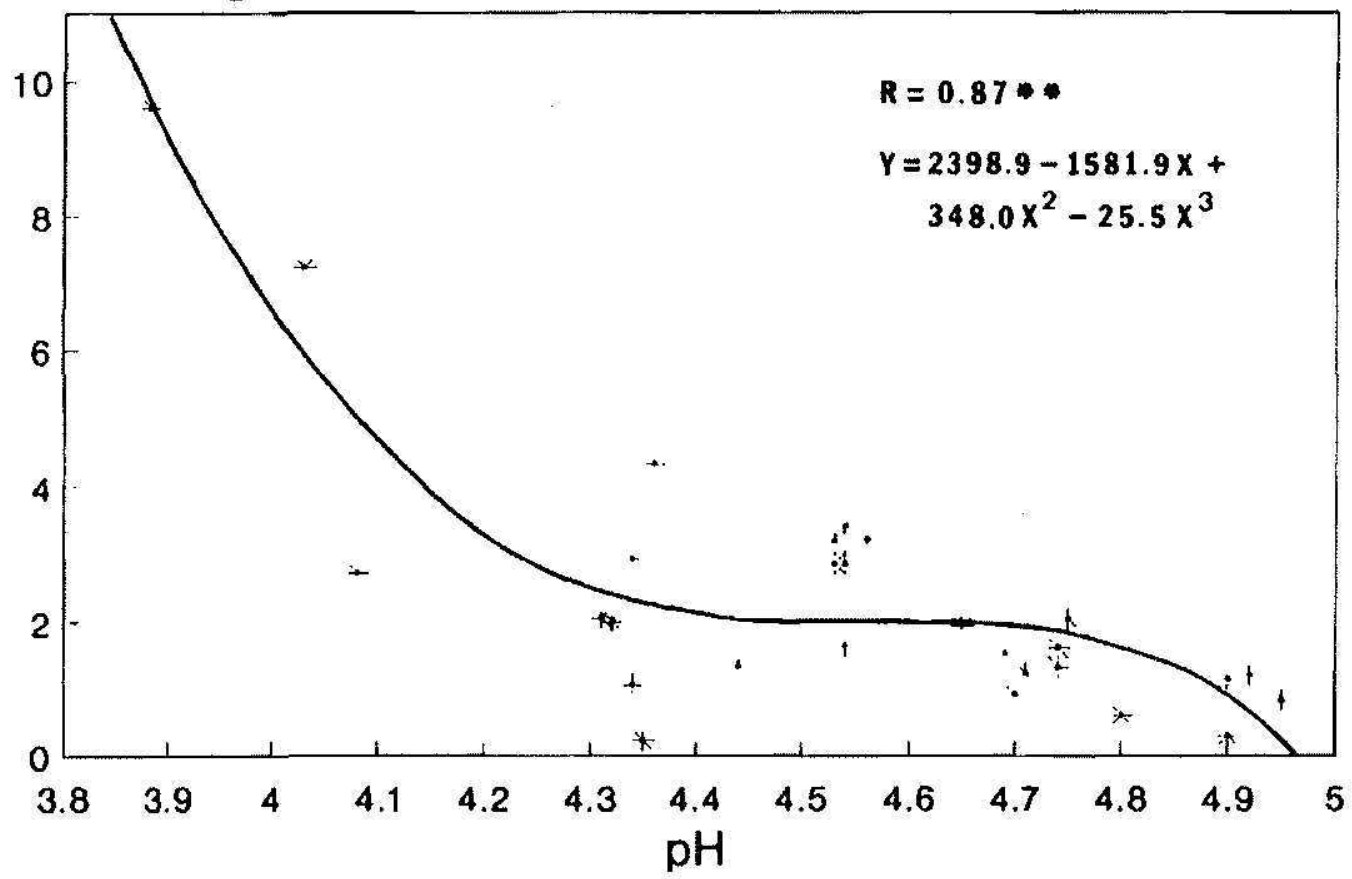

Fig. 5. - Relationship between soil $\mathrm{pH}$ and sugarcane yield (tons cane/acre) for Yabucoa and Humacao areas. 
Also, detailed production records for individual farms are not always available; thus, data variability increases.

\section{DISCUSSION AND RECOMMENDATIONS}

Ine majority of the soils under investigation have $\mathrm{pH}$ levels below 5.5. The findings agree with those of Samuels (8). The absence of a sound liming program for sugarcane areas with low $\mathrm{pH}$ soils has worsened the problem. As a result, other soil fertility components have become limiting factors for sugarcane production, especially low $\mathrm{P}$ and $\mathrm{K}$, and high levels of exchangeable Al. Because an effective industry fertilization program is not currently implemented in Puerto Rico, low levels of fertilizer application are all too common.

Soils from the Coloso area contain threefold more $\mathrm{Al}^{+3}$ than YabucoaHumacao soils and very high percentages of Al saturation. This fact, together with lower \% BS of Coloso soils is expected to aggravate $\mathrm{Al}^{+3}$ toxicity problems. Consequently, liming of these soils is a major priority.

Because of the limitations of the present study, it would not be realistic to state that low soil $\mathrm{pH}$ is the sole factor responsible for the low sugarcane yields in Puerto Rico during the last 2 decades. In fact, other limiting factors become evident with a simple glance at a sugarcane field in most areas of Puerto Rico. These include poor soil preparation, poor or no weed and pest control, improper fertilization practices, and lack of a judicious harvesting schedule. With sound field management practices as described by "Conjunto Tecnológico para la Producción de Caña de Azúcar" (4), including a proper liming program to maintain soil $\mathrm{pH}$ near 5.5 , cane and sugar yields could be dramatically increased, becoming more economically attractive to farmers and the sugarcane industry.

\section{LITERATURE CITED}

1. Barber, S. A., 1984. Soil Nutrient Bioavailability. Wiley and Sons, New York.

2. Bear, F. E. and S. J. Toth, 1948. Influence of calcium on the availability of other soil cations. Soil Sci. 65: 69-75.

3. Departamento de Agricultura, 1982-83. Facts and Figures on Puerto Rico's Agriculture. Oficina de Estadísticas Agrícolas, Santurce, Puerto Rico.

4. Estación Experimental Agrícola, 1983. Conjunto Tecnológico para la Producción de Caña de Azúcar. Publicación Num. 103 (Revisada), Esta. Exp. Agric. Univ. P. R.

5. —_ 1986. La situación económica de la empresa de caña de azúcar. Oficina de Estadísticas Agrícolas, Recinto Univ. de Mayagüez.

6. Lugo-Lopez, M. A. and Luis H. Rivera, 1975. Taxonomic classification of the soils of Puerto Rico. Bull. Num. 245, Agric. Exp. Stn., Univ. P. R.

7. Page, A. L., R. H. Miller, and D. R. Keeney, 1982. Methods of Soil Analysis. Part 2-Chemical and Microbiological Properties. Second ed. Am. Soc. Agron., Madison Wisconsin.

8. Samuels, G.. 1961. La cal que requieren los suelos que se dedican a la caña de azúcar en Puerto Rico. Publicación Miscelánea Num. 40, Esta. Exp. Agric. Univ. P. R.

9. Tisdale, S. L. and W. L. Nelson. 1966. Soil Fertility and Fertilizers. The Macmillan Company, New York. 